\title{
Effect of grass maturity and starch supplementation on nutrient digestibility in dairy cows
}

\author{
$A M$ van Vuuren, $\mathrm{H}$ de Visser, $\mathrm{CJ}$ van der Koelen, A Klop \\ DLO-Institute for Animal Science and Health (ID-DLO), PO Box 160, 8200 AD Lelystad, The Netherlands
}

Digestion of fibre from more mature grass is lower than from young grass, due to increased cell-wall lignification. Starch in diets for dairy cows can reduce fibre digestion. In a $2 \times 2$ factorial experiment we examined the possibility of interaction between forage maturity and starch supplementation in dairy cows.

Four lactating cows were fed totally mixed rations containing grass silage, pressed beet pulp and starch-free concentrates. Two grass silages were used made from grass harvested at different stages of maturity, resulting in neutral detergent fibre (NDF) concentrations of 394 and $464 \mathrm{~g} / \mathrm{kg}$ dry matter (DM) for "young" silage (YS) and "mature" silage (MS), respectively. Diets were offered as such or supplemented with $4 \mathrm{~kg}$ /day of flaked maize. After a 3-week adaptation period, faeces were collected quantitatively on 5 consecutive days. Samples of feed ingredients, refusals and faeces were dried at $70^{\circ} \mathrm{C}$ and analyzed for DM, ash, Kjeldahl-N and NDF. Results were analyzed statistically (ANOVA) with cows and periods as blocks and grass maturity, starch supplementation and their interaction (maturity $x$ starch) as treatment variables.

Daily DM intake varied between 20.4 and $16.7 \mathrm{~kg}$ for diets with and without starch, respectively. Digestibility coefficients of DM, organic matter (OM) and crude protein (CP) of the diets based on MS were lower than those based on YS (Table). Digestibility of NDF did not differ between silages. Inclusion of starch in the diet decreased CP and NDF digestibility on both silages. For MS, starch also decreased DM and OM digestibility. Although the reduction in NDF digestibility by starch supplementation tended to be higher for the MS diet, no significant starch $\mathrm{x}$ maturity interaction was observed ( $P=0.33$ ). Grant (1994, J Dairy Sci, $77,1563-1569$ ) studied the effect of starch source on in vitro digestion in lucerne and bromegrass hay and observed a significant forage $x$ starch interaction. The absence of such an interaction in our study may be due to smaller differences between forages in NDF content and digestibility than observed by Grant (1994).

\begin{tabular}{|c|c|c|c|c|}
\hline & \multicolumn{2}{|c|}{ “Young" silage } & \multicolumn{2}{|c|}{ "Mature" silage } \\
\hline & no starch & $4 \mathrm{~kg}$ starch & no starch & $4 \mathrm{~kg} \mathrm{starch}$ \\
\hline Dry matter & $0.78^{a}$ & $0.77^{a b}$ & $0.76^{\mathrm{b}}$ & $0.74^{\mathrm{c}}$ \\
\hline Organic matter & $0.81^{a}$ & $0.80^{\mathrm{ab}}$ & $0.80^{\mathrm{b}}$ & $0.78^{c}$ \\
\hline Crude protein & $0.78^{a}$ & $0.69^{b}$ & $0.73^{\mathrm{c}}$ & $0.64^{d}$ \\
\hline Neutral detergent fibre & $0.84^{a}$ & $0.79^{b}$ & $0.84^{a}$ & $0.76^{\mathrm{b}}$ \\
\hline
\end{tabular}

$a, b, c, d$ Within a row, means not sharing common superscripts differ $(P<0.05)$ 